\title{
Invitro Efficacy of Bio-Agents against Gray Mold of Orange caused by Botrytis cinerea
}

\author{
Sania Pallabi Reang* \\ Department of Plant Pathology, School of Agricultural, Uttaranchal University, \\ Dehradun-248007, Uttarakhand, India \\ *Corresponding author
}

\section{A B S T R A C T}

\section{Keywords}

Bio-agents, Botrytis cinerea, Gray mold, Orange

\section{Article Info}

Accepted:

18 May 2020

Available Online:

10 June 2020
Three bio-agents i.e. Trichoderma viridae, Trichoderma harzianum and Trichoderma aspergillum were evaluated against Botrytis cinerea under in vitro condition. Culture disc of fungal bio-agents and pathogen were taken from the growing cultures and transferred to PDA contained in $70 \mathrm{~mm}$ petridishes on opposite sides approximately at one $\mathrm{cm}$ from the wall of the plate. Among these three bio-gents Trichodema harzianum showed best mycelial growth inhibition of Botrytis cinerea.

\section{Introduction}

Citrus is the collective term containing a number of species and varieties of fruits, known to world over for their characteristic flavor and attractive range of colours. The orange (Citrus sinensis) is the fruit of citrus species. Ctrus sinensis is also called as sweet orange which is differentiate it from the bitter orange (Citrus aurantium). The juice of orange includes about 12 percent sugars, 0.51.5 percent titrable acidity and other soluble solids, 1 percent citric acid, about $50 \mathrm{mg}$ vitamin $\mathrm{C}$ per $100 \mathrm{ml}$ of juice and about 70-90 percent water.
The origins of most citrus fruits are to be the Southern slope of Himalayan region, the entire north-eastern region of India and adjacent China. Oranges have their origin in China.

The major producers of oranges are Mexico, USA, India and Argentina. Oranges are extensively grown in Nagpur regions of Maharashtra, Coorg of Karnataka, Darjeeling of West Bengal, Sikkim, North-Eastern region of India, Himachal Pradesh and Punjab. Orange is attacked by number of fungal, bacterial, and viral diseases out of which Gray mold is measured as most important disease 
for low yields of oranges which is caused by fungus. Gray mold is also identified as Botrytis rot and bunch rot. It is prevalent all over the world where oranges are grown. Gray mold disease is affected by fungus Botrytis cinerea.

Under favorable condition, this fungus attacks all the fleshy tissues having high sugar, however, maximum damage is noticed in fruits at the harvest time along with during transport and storage. By the attack of Botrytis the mycelium colonizes the fruit coating and destroys epidermal cells thereby agree too much dehydration of water through cuticle.

The most prominent symptoms of the disease are found on the fruits. In fruits the first signs are small, circular, faintly cleared spot. Infected part of fruits become grey coloured and show hairy mycelium in grey coloured all above the surface of fruits.

Often the fungus can be seen developing with the cracks and splits on the fruits. Bunches of conidiophores and conidia swell from stomata and peri-stomatal cracks on the skin of the fruits.

\section{Materials and Methods}

The research on gray mold (Botrytis cinerea)of orange was carried out in the Plant Pathology Lab, Uttaranchal School of Agricultural, Uttaranchal University, Dehradun, Uttarakhand, India. (2019-2020)

\section{Isolation of the pathogen}

Collected infected fruits were used for isolation. Infected part of the fruits were transferred directly by niddle to petriplates containing sterilized PDA medium. These plates were incubated at $22 \pm 1^{\circ} \mathrm{C}$ for four days to obtain good growth of the pathogen.

\section{Purification and maintenance of pure culture}

The culture of the pathogen was purified by dividing the single spore and maintained on PDA slants in refrigerator at $4{ }^{\circ} \mathrm{C}$ and subcultured once in 15 day and used for further studies.

\section{Identification of the fungus}

The greyish mycelium was observed under the high power (40X) microscope from the petriplates for confirmation the identity of the fungus. Under microscope the branches of conidiophores are shown which have rounded apical cells bearing clusters of conidia. The conidiophores and clusters of conidia look like a grape shape cluster and they were compared with original description of the fungus.

\section{In vitro efficacy of bio control agents}

$20 \mathrm{ml}$ of sterilized PDA medium was plated in $70 \mathrm{~mm}$ petriplates. Culture disc of fungal bio-agents and pathogen were taken from the growing cultures and transferred to PDA contained in $70 \mathrm{~mm}$ petridishes on opposite sides approximately at one $\mathrm{cm}$ from the wall of the plate.

For each treatment four replications were maintained and control plates were maintained by placing only the pathogen and incubated at $22 \pm 1^{\circ} \mathrm{C}$. The colony growth of the fungal bio-agents and test pathogen were recorded by periodical observation.

The percent of inhibition growth was calculated by using the formula-

$\mathrm{I}=100(\mathrm{C}-\mathrm{T}) / \mathrm{C}$

$\mathrm{I}=$ Percent inhibition of mycelium growth

$\mathrm{C}=$ Growth of mycelium in control

$\mathrm{T}=$ Growth of mycelium in treatment . 


\section{Results and Discussion}

Three fungal bio agents were evaluated against the pathogen B.cinerea under invitro condition. Out of three bioagents, T.harzianum showed maximum percent growth inhibition (66.07\%) with the lowest fungal colony diameter $23.75 \mathrm{~mm}$. The next best bioagent was T.viridae and showed 55.35 percent growth inhibition. The bioagent T.aspergillum showed the lowest growth inhibition percent of the pathogen. Among the three species of fungal bioagent T.harzianum showed higher antagonism as compared to other two bioagents against the pathogen B.cinerea.

\section{Discussion}

Three fungal bio agents namely T.viridae, T.harzianum and T.aspergillum were evaluated against B.cinerea. Among these three bio agents T.harzianum showed best growth inhibition $(66.07 \%)$ of the pathogen. This result was in agreement with Alharbi Asmaa A. (2018) who reported that T.harzianum was very effective bio agent for B.cinerea in in vitro condition.

But X. Xu et al., (2010) reported that combination of biocontrol agents gave very effective against B.cinerea on strawberry leaves.

Table.1 Name of three bio-agents

\begin{tabular}{|c|}
\hline Name of bio agents \\
\hline Trichoderma viridae \\
\hline Trichoderma harzianum \\
\hline Trichoderma aspergillum \\
\hline
\end{tabular}

Table.2 Effect of bio-agents on colony growth of Botrytis cinerea

\begin{tabular}{|l|c|}
\hline Name of bioagent & $\begin{array}{c}\text { Colony growth }\left(\mathbf{m m}^{*}\right) \\
\text { on bio-agents }\end{array}$ \\
\hline Trichoderma viridae & 31.25 \\
\hline Trichoderma harzianum & 23.75 \\
\hline Trichoderma aspergillum & 33.75 \\
\hline Control & 70 \\
\hline SE(m) & 0.98 \\
\hline CD & 2.16 \\
\hline
\end{tabular}

Table.3 Effect of bio-agents on growth inhibition of Botrytis cinerea

\begin{tabular}{|l|c|}
\hline Name of bio agent & Growth inhibition \% \\
\hline Trichoderma viridae & 55.35 \\
\hline Trichoderma harzianum & 66.07 \\
\hline Trichoderma aspergillum & 51.78 \\
\hline Control & 00 \\
\hline SE(m) & 0.99 \\
\hline CD & 3.08 \\
\hline
\end{tabular}




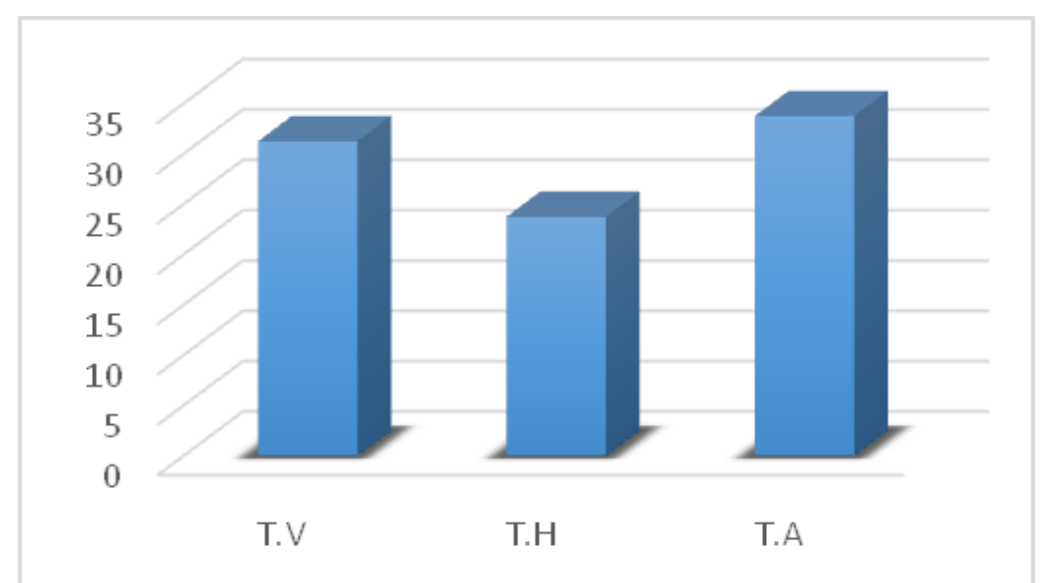

Fig.1 Effect of bio-agents on colony growth of Botrytis cinerea

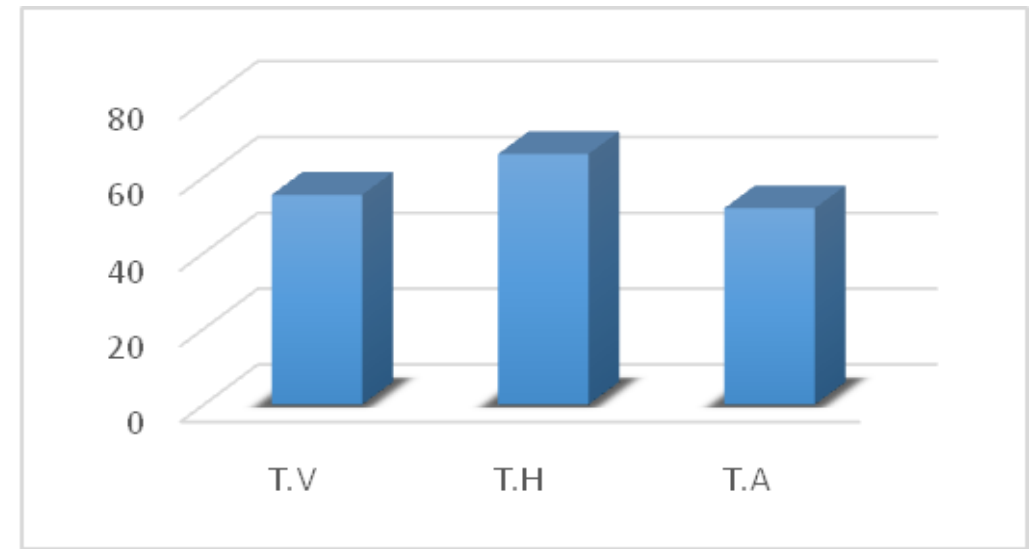

Fig.2 Effect of bio-agents on mycelial growth inhibition of Botrytis cinerea

From this study we showed that Trichoderma harzianum showed best effective mycelial growth inhibition of Botrytis cinerea and it can be used for the control of gray mold of orange.

\section{References}

Alharbi Asmaa A. (2018). Effectiveness of Acetic Acid, Essential Oils and Trichoderma spp. In controlling Gray mold disease on Cucumber. Alex. J. Agric. Sci., Vol. 63, pp. 275-281.

Gary E. H. (2006). Overview of Mechanisms and Uses of Trichoderma spp. Phytopathology, Vol. 96, pp. 190-193.

Robinson-Boyer L., Mike J., Xiang-Ming X. and Peter J. (2009). Management of Strawberry Grey Mould Using Mixtures of Biocontrol Agents with Different Mechanisms of Action. Biocontrol Science and Technology, Vol. 19, pp. 1051-1065.

Xiangming X., J. Robinson, Mike J. and Peter J. (2010). Using combination of biocontrol agents to control Botrytis cinerea on strawberry leaves under fluctuating temperatures. Biocontrol Science and Technology, Vol. 20, pp. 359-373.

Yigal E. (2000). Trichoderma harzianum T39 preparation for biocontrol of Plant Diseases-Control of Botrytis cinerea, Sclerotinia sclerotiorum and Cladosporium fulvam. Biocontrol sciences and Technology, Vol. 10, pp. 499-507. 


\section{How to cite this article:}

Sania Pallabi Reang. 2020. Invitro Efficacy of Bio-Agents against Gray Mold of Orange caused by Botrytis Cinerea. Int.J.Curr.Microbiol.App.Sci. 9(06): 1785-1789. doi: https://doi.org/10.20546/ijcmas.2020.906.222 